\title{
Role of zinc in insulin regulation and diabetes
}

\author{
Resham Raj Poudel, Yuvaraj Bhusal ${ }^{1}$, Biswaraj Tharu², Nisha Kusum Kafle ${ }^{3}$
}

Department of Internal Medicine, Western Reserve Health Education, Youngstown, OH, USA, ${ }^{1}$ Department of Internal Medicine, BPK Institute of Health Science, Dharan, Nepal, ${ }^{2}$ Department of Internal Medicine and ${ }^{3}$ Public Health, Institute of Medicine, Kathmandu, Nepal

Abstract

Zinc (Zn) affects glucose metabolism through insulin regulation and has potential implication in diabetes. Zn deficiency has not been proven in diabetes; however, observations of hyperzincuria, hypozincemia, and $\mathrm{Zn}$ malabsorption in diabetes indicate additional requirements for $\mathrm{Zn}$. Mutation in $\mathrm{Zn}$ transporter 8 - a key protein in insulin secretion - has been associated with Type 2 diabetes. Zn supplementation in prediabetics and diabetics has been supported to improve plasma glucose, hemoglobin A1c (HbA1c), and lipids and potentially improve insulin sensitivity, reduce oxidative stress, and protect from renal damage.

Keywords: Diabetes, hyperzincuria, hypozincemia, insulin, zinc

Address for correspondence: Dr. Resham Raj Poudel, Western Reserve Health Education, Youngstown, OH, USA.

E-mail: poudelresham@gmail.com

Received: 24.04.2017, Accepted: 02.05.2017

\section{INTRODUCTION}

According to the World Health Organization statistics, 422 million people had diabetes in 2014. In 2012 alone, 1.5 million people died due to diabetes. ${ }^{[1]}$ The Centers for Disease Control and Prevention reports that more than 29 million Americans have diabetes and 86 million, i.e., $>1 / 3^{\text {rd }}$ of total American population, have prediabetes. ${ }^{[2]}$ Search for new approach for addressing glucose control is always on the run, be it drugs, diet, or activity influencing glucose metabolism. Here, we discuss the role of zinc ( $\mathrm{Zn})$ in insulin regulation and implication in diabetes.

\section{ZINC PHYSIOLOGY}

$\mathrm{Zn}$ is a vital mineral involved in numerous aspects of cellular metabolism. It is widely distributed in variety of food including oyster, red meat, poultry, beans, nuts, and whole grains. ${ }^{[3]} \mathrm{Zn}$ is an essential component of more than 300 catalytic enzymes in our body. ${ }^{[4,5]}$ It plays a role

\begin{tabular}{|l|l|}
\hline \multicolumn{2}{|c|}{ Access this article online } \\
\hline Quick Response Code: & Website: \\
\hline & www.joshd.net \\
\cline { 2 - 2 } & DOI: \\
& 10.4103/joshd.J_Soc_Health_ \\
\hline
\end{tabular}

in DNA synthesis, protein synthesis, cell division, immune function, and wound healing. ${ }^{[6,7]}$ It supports normal growth and development ${ }^{[8]}$ and is also required for proper sense of taste and smell. ${ }^{\left[{ }^{[0]}\right.}$ The $\mathrm{Zn}$ content in pancreatic $\beta$-cells is among the highest of the body and it appears to be an important metal for insulin-secreting cells. ${ }^{[10]} \mathrm{A}$ daily intake of $\mathrm{Zn}$ is required to maintain a steady state because the body has no specialized system to store it. ${ }^{[1]}$ The distribution of $\mathrm{Zn}$ throughout the body in various proteins and nucleic acids makes it difficult to accurately measure the levels using laboratory tests. ${ }^{[12]}$ Plasma or serum $\mathrm{Zn}$ levels, which are commonly used for evaluating $\mathrm{Zn}$ deficiency, do not accurately reflect cellular Zn status due to highly regulated homeostatic control mechanisms. ${ }^{[13]}$ $\mathrm{Zn}$ deficiency may be present in the absence of abnormal laboratory indices. ${ }^{[8]} \mathrm{Zn}$ deficiency occurs due to inadequate $\mathrm{Zn}$ intake or absorption, increased loss of $\mathrm{Zn}$ from the body, or increased requirements for $\mathrm{Zn}^{.{ }^{[14]} \mathrm{Zn} \text { deficiency }}$ has not been very well documented in diabetes; however, it is suggested that there may be additional requirements for

This is an open access article distributed under the terms of the Creative Commons Attribution-NonCommercial-ShareAlike 3.0 License, which allows others to remix, tweak, and build upon the work non-commercially, as long as the author is credited and the new creations are licensed under the identical terms.

For reprints contact: reprints@medknow.com

How to cite this article: Poudel RR, Bhusal Y, Tharu B, Kafle NK. Role of zinc in insulin regulation and diabetes. J Soc Health Diabetes 2017;5:83-7. 
Zn. Different studies have found decreased physiological measurements of $\mathrm{Zn}$ status in diabetics. Meanwhile, hyperzincuria and indications of $\mathrm{Zn}$ malabsorption have also been observed in both Type 1 and Type 2 diabetics. ${ }^{[15]}$

\section{THE ROLE OF ZINC IN INSULIN REGULATION}

Zn plays a substantial role in insulin regulation and carbohydrate metabolism. ${ }^{[16]} \mathrm{Zn}$ plays a key role in the storage and secretion of insulin by pancreas, which subsequently increases the uptake of glucose. ${ }^{[17]}$ Low plasma level of $\mathrm{Zn}$ adversely affects the ability of islet cells to produce and secrete insulin. ${ }^{[17]}$ Insulin is produced in the $\beta$-cells through preproinsulin and proinsulin precursors. In the Golgi apparatus of $\beta$-cells, proinsulin is stored along with $\mathrm{Zn}$ and calcium ions as hexamers, which is then converted into insulin hexamers after excision of c-peptide by proteolytic enzymes. These insulin hexamers have low solubility and are stored as crystals within the secretory vesicles. When these vesicles fuse with the plasma membrane, insulin crystals are expulsed into the intercellular fluid. The insulin crystals then dissolve and dissociate into monomers and these monomers are transported to other tissues through the blood stream and they finally bind to the insulin receptors. ${ }^{[18]} \mathrm{Zn}$ ions have very important role in formation of the crystalline nature of the insulin granule, condensing them and thus reducing contact with the surrounding membrane. ${ }^{[19]}$ $\mathrm{Zn}$ also promotes phosphorylation of Akt and GSK 3B, expression of hexokinase- 2 and inhibits the negative regulators of Akt. These have significant roles in increasing expression of glucose transport type 4 and metabolism while decreasing cellular apoptosis, hyperglycemia, and excess glucose in kidney tissues. ${ }^{[20]}$

\section{METALLOTHIONEINS, ZINC TRANSPORTERS, AND INHIBITORS: ROLE IN INSULIN METABOLISM}

There are three classes of protein which control the concentration of $\mathrm{Zn}$ in the cytoplasm. Metallothioneins, $\mathrm{Zn}$ transporters ( $\mathrm{ZnTs}$ ) encoded by solute linked carrier 30 (SLC30) and Zrt, Irt-like proteins (ZIPs) encoded by SLC39 genes. ${ }^{[21]}$ Metallothioneins control $Z n$ availability in $\beta$-cells. When $\mathrm{Zn}$ is needed for formation of $\mathrm{Zn}$ proteins, the metallothioneins release $\mathrm{Zn}$. If there is excess $\mathrm{Zn}$, it forms metallothionein. ${ }^{[22]} \mathrm{ZnTs}$ function to reduce cytoplasmic $\mathrm{Zn}$ concentration by transporting them to intracellular vesicles or extracellular spaces. ${ }^{[2,24]}$ There are nine forms of ZnTs named from ZnT1-8 and ZnT10. ${ }^{[25]}$ ZnT8, encoded by SLC30A8 belongs to cation diffusion facilitator family. ${ }^{[10]}$ It delivers $\mathrm{Zn}$ into the granules for insulin maturation and secretion ${ }^{[24]}$ as shown in Figure 1. ${ }^{[2]]}$ Studies have shown that ZnT8 overexpression leads to increased glucose-stimulated insulin secretion, especially for high glucose challenge and protection from $\mathrm{Zn}$ depletion-induced cell death. ${ }^{[23]}$ Similarly, ZnT8 knockdown is associated with increased intracellular insulin with reduced insulin secretion and increased apoptosis of $\beta$-cells, as well as increased hepatic insulin clearance and low peripheral blood insulin. Zn decreases hepatic insulin clearance by inhibiting clathrin-dependent insulin endocytosis. ${ }^{[27,28]} \mathrm{It}$ is well established that $\mathrm{ZnT}$ T8 is a key protein for the regulation of insulin secretion from the pancreatic $\beta$-cells, and its mutation has been associated with Type 2 diabetes mellitus (T2DM). ${ }^{[2]}$ Roles of other ZnTs have been identified such as ZnT3 knockdown has been also associated with decreased insulin secretion as well as apoptosis of $\beta$-cells. ${ }^{[23,27]}$ Similarly, ZnT7 overexpression results in increased insulin synthesis while ZnT7 knockdown results in low glucose uptake and increased lipogenesis in adipocytes. ${ }^{[30]} \mathrm{Zn}$ chelation inhibits ZnT8 and insulin expression, leading to diabetes as well as apoptosis of $\beta$-cells. ${ }^{[31]}$ ZIPs increase cytoplasmic $\mathrm{Zn}$ concentrations, especially during low glucose exposure. ${ }^{[22,23]}$ ZIP6 also facilitates the protective effect of glucagon-like peptide 1 on $\beta$-cell survival. ${ }^{[32]}$

\section{Human Islet Amyloid Polypeptide and zinc}

Human Islet Amyloid Polypeptide, an amyloidogenic protein, is cosecreted with insulin in response to glucose. It is found in pancreatic islets especially of diabetic patients and is linked to loss of $\beta$-cells. ${ }^{[3]} \mathrm{Zn}$ promotes the formation of oligomers while it inhibits the formation of amyloid fibers. ${ }^{[34]}$

\section{NORMAL SERUM ZINC, URINE ZINC EXCRETION CHANGES IN DIABETES}

Normal serum $\mathrm{Zn}$ level in healthy individuals varies from 0.66 to $1.10 \mathrm{mcg} / \mathrm{mL} .{ }^{[34]}$ Fecal excretion of $\mathrm{Zn}$ is the

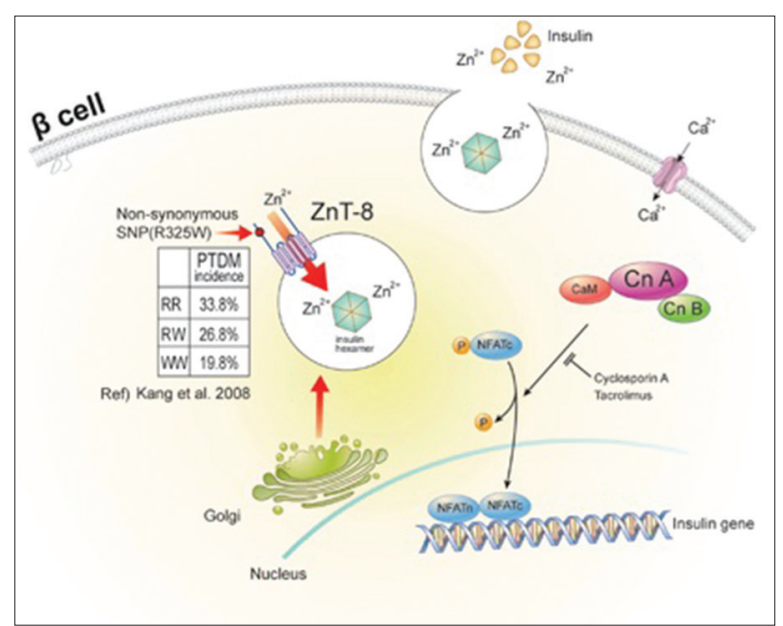

Figure 1: Schematic representation of vesicular Zinc transporter-8 expression and R325W polymorphism in pancreatic islet $\beta$-cells ${ }^{[26]}$ 
dominant route of elimination. Renal excretion is a minor secondary elimination pathway. Normal daily excretion of $\mathrm{Zn}$ in the urine ranges from 20 to $967 \mathrm{mcg} / 24 \mathrm{~h} .{ }^{[35]}$ The pathophysiology of diabetes has been associated with hyperzincuria and hypozincemia. ${ }^{[36,37]} \mathrm{Zn}$ deficiency is more common in developing countries, where diabetes is also showing an exponential rise. ${ }^{[38,39]}$ Type 2 diabetic patients have suboptimal $\mathrm{Zn}$ level in blood due to increased urinary depletion (hyperzincuria) resulting hypozincemia. ${ }^{[40]}$ A comparative study showed serum $\mathrm{Zn}$ levels as $64.2 \pm 12.6 \mu \mathrm{g} / \mathrm{dl}$ for T1DM versus $68.9 \pm 11.9 \mu \mathrm{g} / \mathrm{dl}$ for T2DM versus $83.4 \pm 12.5 \mu \mathrm{g} / \mathrm{dl}$ for healthy controls. ${ }^{[41]}$ However, in other studies, diabetic patients despite having excess urinary excretion of $\mathrm{Zn}$ had normal serum $\mathrm{Zn}$ levels, possibly from compensatory hyperabsorption or increased $\mathrm{Zn}$ content in the diabetic diet. ${ }^{[42]}$ Zincuria has been associated with hyperglycemia, polyuria, glycosuria, and proteinuria. ${ }^{[43-45]}$ Urinary Zn excretion has been shown to be higher in diabetics than in controls $(P<0.0001)$ and was significantly correlated with urine glucose $(P<0.004)$ and volume $(P<0.0007) \cdot{ }^{[43]}$ In comparison to controls, T1DM women lost 4 times more protein in urine, and the urinary protein loss correlated with the urinary $\mathrm{Zn}$ loss $(P<0.007) \cdot{ }^{[44]}$ Zincuria was higher in patients with excessive microalbuminuria $(>15 \mathrm{mg} / \mathrm{L})(P<0.001)$, although zincuria and microalbuminuria did not correlate significantly. ${ }^{[45]}$

\section{EFFECTS OF ZINC SUPPLEMENTATION IN DIABETES}

$\mathrm{Zn}$ supplementation has been supported to improve $\mathrm{Zn}$ level, glucose metabolism, lipid profile, and proteinuria. In a meta-analysis, there was a significant increment in serum $\mathrm{Zn}$ levels $(2.42 \pm 0.25 \mu \mathrm{mol} / \mathrm{L}, P<0.001)$ in patients with T2DM after $\mathrm{Zn}$ supplementation. ${ }^{[46]}$ Some studies have shown that $\mathrm{Zn}$ supplementation increased high-density lipoprotein (HDL) cholesterol levels while significantly reduced fasting and postprandial blood glucose, HbA1c, plasma total cholesterol, low-density lipoproteins cholesterol, and triglycerides levels. ${ }^{[41,47,48]}$ In a study, $\mathrm{Zn}+$ multivitamin/mineral (MVM) group had a significant mean change of fasting plasma glucose (FPG) $-0.33 \mathrm{mmol} / \mathrm{L}$ (standard error of the mean $0.21 \mathrm{mmol} / \mathrm{L})(P=0.05)$ when compared with the other two groups (mean change in the MVM group $+0.19(0.31) \mathrm{mmol} / \mathrm{L}$ and $+0.43(0.23) \mathrm{mmol} / \mathrm{L}$ in the control group, respectively). ${ }^{[4]}$ In 12 different studies comparing the effects of $\mathrm{Zn}$ supplementation in FPG in T2DM, the pooled mean difference in FPG between $\mathrm{Zn}$ supplemented and placebo groups was $18.13 \mathrm{mg} / \mathrm{dl} .2 \mathrm{~h}$ postprandial blood sugar also showed a similar distinct reduction $(34.87 \mathrm{mg} / \mathrm{dl})$ in the $\mathrm{Zn}$-treated group. The reduction in $\mathrm{HbA} 1 \mathrm{c}$ was $0.54 \%$ in the Zn-treated group. ${ }^{[49]} \mathrm{A}$ study showed decreased HDL cholesterol $(-0.10 \pm 0.02 \mathrm{mmol} / \mathrm{L}, P<0.001)$ after $\mathrm{Zn}$ supplementation, equivalent to a $7 \%$ decrease from baseline in healthy individuals. ${ }^{[46]}$ However, on comparing 8 studies in T2DM, the pooled mean difference for total cholesterol between $\mathrm{Zn}$ supplemented and placebo groups was $32.37 \mathrm{mg} / \mathrm{dl}(P<0.05)$. Low-density lipoprotein also showed a distinct reduction in the $\mathrm{Zn}$-treated group; the pooled mean difference from random effects analysis was $11.19 \mathrm{mg} / \mathrm{dl}(P<0.05) \cdot{ }^{[49]}$ A double-blind randomized controlled trial with $\mathrm{Zn}$ supplementation for 3 months showed a significant reduction in albumin excretion, from $90 \pm 60$ to $85 \pm 57 \mathrm{mg} / \mathrm{g}$ creatinine $(P=0.003)$. This outcome might be due to the antioxidant effect of $\mathrm{Zn} .{ }^{\left[{ }^{[4]}\right.} \mathrm{Zn}$ supplementation improves insulin resistance in obese individuals of both sexes. ${ }^{[50]}$ Prediabetic adults who took daily oral $\mathrm{Zn}$ supplementation also improved their FPG $(5.37 \pm 0.20 \mathrm{mmol} / \mathrm{L}$ vs. $5.69 \pm 0.26, P<0.001)$, $\beta$-cell function, and insulin sensitivity over 6 months compared to placebo group. ${ }^{[1]}$

\section{Zn supplementation decreases oxidative stress}

Hyperglycemia increases oxidative stress in DM. ${ }^{[5]} \mathrm{Zn}$ may protect the cells from oxidative injury decreasing blood glucose levels. $\mathrm{Zn}$ administration alone or combined with chromium decreased plasma thiobarbituric acid reactive substances' (TBARS) levels - an oxidant which is increased in diabetics. An inverse correlation was found between Zn plasma levels and plasma TBARS. ${ }^{[53]}$ After 6 months of $\mathrm{Zn}$ supplementation, there was a 15\% decrease of plasma TBARS with no significant changes in the placebo group. ${ }^{[53]}$ In animal study involving diabetic rats with $\mathrm{Zn}$ administration, glutathione levels increased; whereas, lipid peroxidation, nonenzymatic glycosylation, urea, and creatinine levels decreased in their kidneys. ${ }^{[5]}$

\section{Zn supplementation protects from kidney damage} Zn supplementation in T1DM rats showed fewer pathological changes in kidney compared to a placebo as evidenced by lower levels of glomerular basement membrane thickness, mesangial index and tubulointerstitial damage. ${ }^{[55,56]}$

\section{CONCLUSION}

Zn deficiency can occur from insufficient intake, malabsorption, excess excretion, and increased utilization, and this deficiency exists, particularly in developing countries where the prevalence of diabetes (mostly T2DM) is also rising. The physiology of $\mathrm{Zn}$ in insulin regulation has been well established for long. Zn plays a role in formation, release, and transport of insulin molecules. Different $\mathrm{ZnTs}$ 
including ZnT8, ZnT3, and ZIP6 have specific roles in insulin pathway. There is no evidence associating $\mathrm{Zn}$ deficiency with incidence of diabetes; however, the fact that hyperzincuria and hypozincemia has been observed in people with diabetes and cellular $\mathrm{Zn}$ deficiency can occur even with normal blood $\mathrm{Zn}$ levels points toward some role of $\mathrm{Zn}$ in diabetes and potential of $\mathrm{Zn}$ supplementation and or optimization. Zn supplementation has been observed in several studies to positively affect glucose, A1c, and lipid levels in diabetics, with potential for decreasing oxidative stress and protecting from renal damage. At this time, we have no guidelines for $\mathrm{Zn}$ measurement or supplementation in diabetes; however, ensuring $\mathrm{Zn}$ as a part of regular dietary requirement through healthy food or oral supplementation would positively affect diabetes health.

\section{Financial support and sponsorship}

Nil.

\section{Conflicts of interest}

There are no conflicts of interest.

\section{REFERENCES}

1. Global Report on Diabetes. World Health Organization; 2017. Available from: http://www.who.int/diabetes/global-report/en. [Last cited on 2017 Mar 23].

2. Diabetes. Centers for Disease Control and Prevention; 2016. Available from: https://www.cdc.gov/chronicdisease/resources/publications/ aag/diabetes.htm. [Last cited on 2017 Mar 23].

3. Office of Dietary Supplements - Zinc. National Institutes of Health. U.S. Department of Health and Human Services. Available from: https:// www.ods.od.nih.gov/factsheets/Zn-HealthProfessional/. [Last cited on 2017 Mar 23].

4. Jansen J, Karges W, Rink L. Zinc and diabetes - Clinical links and molecular mechanisms. J Nutr Biochem 2009;20:399-417.

5. Khan AR, Awan FR. Metals in the pathogenesis of type 2 diabetes. J Diabetes Metab Disord 2014;13:16.

6. Solomons NW. Mild human zinc deficiency produces an imbalance between cell-mediated and humoral immunity. Nutr Rev 1998;56(1 Pt 1):27-8.

7. Prasad AS. Zinc: An overview. Nutrition 1995;11 1 Suppl:93-9.

8. Maret W, Sandstead HH. Zinc requirements and the risks and benefits of zinc supplementation. J Trace Elem Med Biol 2006;20:3-18.

9. Prasad AS, Beck FW, Grabowski SM, Kaplan J, Mathog RH. Zinc deficiency: Changes in cytokine production and T-cell subpopulations in patients with head and neck cancer and in noncancer subjects. Proc Assoc Am Physicians 1997;109:68-77.

10. Chimienti F, Favier A, Seve M. ZnT-8, a pancreatic beta-cell-specific zinc transporter. Biometals 2005;18:313-7.

11. Rink L, Gabriel P. Zinc and the immune system. Proc Nutr Soc 2000;59:541-52.

12. Hambidge KM, Krebs NF. Zinc deficiency: A special challenge. J Nutr 2007;137:1101-5.

13. Van Wouwe JP. Clinical and laboratory assessment of zinc deficiency in Dutch children. A review. Biol Trace Elem Res 1995;49:211-25.

14. King JC, Cousins RJ. Zinc. In: Shils ME, Shike M, Ross AC, Caballero B, Cousins, RJ, editors. Modern Nutrition in Health and Disease. $10^{\text {th }}$ ed. Baltimore, MD: Lippincott Williams \& Wilkins; 2005. p. 271-85.
15. Salgueiro MJ, Krebs N, Zubillaga MB, Weill R, Postaire E, Lysionek AE, et al. Zinc and diabetes mellitus: Is there a need of zinc supplementation in diabetes mellitus patients? Biol Trace Elem Res 2001;81:215-28.

16. Chausmer AB. Zinc, insulin and diabetes. J Am Coll Nutr 1998;17:109-15.

17. Rungby J. Zinc, zinc transporters and diabetes. Diabetologia 2010;53:1549-51.

18. Dunn MF. Zinc-ligand interactions modulate assembly and stability of the insulin hexamer - A review. Biometals 2005;18:295-303.

19. Emdin SO, Dodson GG, Cutfield JM, Cutfield SM. Role of zinc in insulin biosynthesis. Some possible zinc-insulin interactions in the pancreatic B-cell. Diabetologia 1980;19:174-82.

20. Sun W, Wang Y, Miao X, Wang Y, Zhang L, Xin Y, et al. Renal improvement by zinc in diabetic mice is associated with glucose metabolism signaling mediated by metallothionein and Akt, but not Akt2. Free Radic Biol Med 2014;68:22-34.

21. Davidson HW, Wenzlau JM, O’Brien RM. Zinc transporter 8 (ZnT8) and $B$ cell function. Trends Endocrinol Metab 2014;25:415-24.

22. Maret $\mathrm{W}$. The function of zinc metallothionein: A link between cellular zinc and redox state. J Nutr 2000;130 5S Suppl: 1455S-8S.

23. Smidt K, Jessen N, Petersen AB, Larsen A, Magnusson N, Jeppesen JB, et al. SLC30A3 responds to glucose-and zinc variations in beta-cells and is critical for insulin production and in vivo glucose-metabolism during beta-cell stress. PLoS One 2009;4:e5684.

24. Huang L. Zinc and its transporters, pancreatic B-cells, and insulin metabolism. Vitam Horm 2014;95:365-90.

25. Kambe T. Molecular architecture and function of $\mathrm{ZnT}$ transporters. Curr Top Membr 2012;69:199-220.

26. Kim I, Kang ES, Yim YS, Ko SJ, Jeong SH, Rim JH, et al. A low-risk ZnT-8 allele (W325) for post-transplantation diabetes mellitus is protective against cyclosporin A-induced impairment of insulin secretion. Pharmacogenomics J 2011;11:191-8.

27. Petersen AB, Smidt K, Magnusson NE, Moore F, Egefjord L, Rungby J. siRNA-mediated knock-down of ZnT3 and ZnT8 affects production and secretion of insulin and apoptosis in INS-1E cells. APMIS 2011;119:93-102.

28. Tamaki M, Fujitani Y, Hara A, Uchida T, Tamura Y, Takeno K, et al. The diabetes-susceptible gene SLC30A8/ZnT8 regulates hepatic insulin clearance. J Clin Invest 2013;123:4513-24.

29. Wijesekara N, Dai FF, Hardy AB, Giglou PR, Bhattacharjee A, Koshkin $\mathrm{V}$, et al. Beta cell-specific Znt8 deletion in mice causes marked defects in insulin processing, crystallisation and secretion. Diabetologia 2010;53:1656-68.

30. Tepaamorndech S, Kirschke CP, Pedersen TL, Keyes WR, Newman JW, Huang L, et al. Zinc transporter 7 deficiency affects lipid synthesis in adipocytes by inhibiting insulin-dependent Akt activation and glucose uptake. FEBS J 2016;283:378-94.

31. Liu Y, Batchuluun B, Ho L, Zhu D, Prentice KJ, Bhattacharjee A, et al. Characterization of zinc influx transporters (ZIPs) in pancreatic B Cells: Roles in regulating cytosolic zinc homeostasis and insulin secretion. J Biol Chem 2015;290:18757-69.

32. Brender JR, Hartman K, Nanga RP, Popovych N, de la Salud Bea R, Vivekanandan S, et al. Role of zinc in human islet amyloid polypeptide aggregation. J Am Chem Soc 2010;132:8973-83.

33. Salamekh S, Brender JR, Hyung SJ, Nanga RP, Vivekanandan S, Ruotolo BT, et al. A two-site mechanism for the inhibition of IAPP amyloidogenesis by zinc. J Mol Biol 2011;410:294-306.

34. ZNS-Clinical: Zinc, Serum. Mayo Medical Laboratories. Available from: http://www.mayomedicallaboratories.com/test-catalog/ Clinical+and+Interpretive/8620. [Last cited on 2017 Mar 23].

35. ZNU-Clinical: Zinc, 24 Hour. Mayo Medical Laboratories. Available from: http://www.mayomedicallaboratories.com/test-catalog/ Clinical+and+Interpretive/8591. [Last cited on 2017 Mar 23; Last accessed on 2017 Jan 22].

36. Garg VK, Gupta R, Goyal RK. Hypozincemia in diabetes mellitus. 
J Assoc Physicians India 1994:42:720-1.

37. Pidduck HG, Wren PJ, Evans DA. Hyperzincuria of diabetes mellitus and possible genetical implications of this observation. Diabetes 1970;19:240-7.

38. Black RE. Zinc deficiency, infectious disease and mortality in the developing world. J Nutr 2003;133 5 Suppl 1:1485S-9S.

39. Diabetes. WHO Diabetes Fact Sheet. Available from: http://www. who.int/mediacentre/factsheets/fs312/en/index.html. [Last cited on 2017 Jan 22].

40. Kazi TG, Afridi HI, Kazi N, Jamali MK, Arain MB, Jalbani N, et al. Copper, chromium, manganese, iron, nickel, and zinc levels in biological samples of diabetes mellitus patients. Biol Trace Elem Res 2008;122:1-18.

41. Al-Maroof RA, Al-Sharbatti SS. Serum zinc levels in diabetic patients and effect of zinc supplementation on glycemic control of type 2 diabetics. Saudi Med J 2006;27:344-50.

42. Martín AM, Extremera BG, Soto MF, Martínez MR, Jiménez AG, Morales AG, et al. Zinc levels after intravenous administration of zinc sulphate in insulin-dependent diabetes mellitus patients. Klin Wochenschr 1991;69:640-4.

43. Canfield WK, Hambidge KM, Johnson LK. Zinc nutriture in type I diabetes mellitus: Relationship to growth measures and metabolic control. J Pediatr Gastroenterol Nutr 1984;3:577-84.

44. Heise CC, King JC, Costa FM, Kitzmiller JL. Hyperzincuria in IDDM women. Relationship to measures of glycemic control, renal function, and tissue catabolism. Diabetes Care 1988;11:780-6.

45. Brun JF, Fons C, Fussellier M, Bardet L, Orsetti A. Urinary zinc and its relationships with microalbuminuria in type I diabetics. Biol Trace Elem Res 1992;32:317-23.

46. Foster M, Petocz P, Samman S. Effects of zinc on plasma lipoprotein cholesterol concentrations in humans: A meta-analysis of randomised controlled trials. Atherosclerosis 2010;210:344-52.
47. Gunasekara P, Hettiarachchi M, Liyanage C, Lekamwasam S. Effects of zinc and multimineral vitamin supplementation on glycemic and lipid control in adult diabetes. Diabetes Metab Syndr Obes 2011;4:53-60.

48. Parham M, Amini M, Aminorroaya A, Heidarian E. Effect of zinc supplementation on microalbuminuria in patients with type 2 diabetes: A double blind, randomized, placebo-controlled, cross-over trial. Rev Diabet Stud 2008;5:102-9.

49. Jayawardena R, Ranasinghe P, Galappatthy P, Malkanthi R, Constantine G, Katulanda P. Effects of zinc supplementation on diabetes mellitus: A systematic review and meta-analysis. Diabetol Metab Syndr 2012;4:13.

50. Cruz KJ, Morais JB, de Oliveira AR, Severo JS, Marreiro DD. The effect of zinc supplementation on insulin resistance in obese subjects: A systematic review. Biol Trace Elem Res 2017;176:239-43.

51. Islam MR, Attia J, Ali L, McEvoy M, Selim S, Sibbritt D, et al. Zinc supplementation for improving glucose handling in pre-diabetes: A double blind randomized placebo controlled pilot study. Diabetes Res Clin Pract 2016;115:39-46.

52. Fiorentino TV, Prioletta A, Zuo P, Folli F. Hyperglycemia-induced oxidative stress and its role in diabetes mellitus related cardiovascular diseases. Curr Pharm Des 2013;19:5695-703.

53. Roussel AM, Kerkeni A, Zouari N, Mahjoub S, Matheau JM, Anderson RA. Antioxidant effects of zinc supplementation in Tunisians with type 2 diabetes mellitus. J Am Coll Nutr 2003;22:316-21.

54. Karatug A, Kaptan E, Bolkent S, Mutlu O, Yanardag R. Alterations in kidney tissue following zinc supplementation to STZ-induced diabetic rats. J Trace Elem Med Biol 2013;27:52-7.

55. Tang Y, Yang Q, Lu J, Zhang X, Suen D, Tan Y, et al. Zinc supplementation partially prevents renal pathological changes in diabetic rats. J Nutr Biochem 2010;21:237-46.

56. Fernando J, Zhou S. The role of zinc in renal pathological changes in diabetic status. J Nutr Disord Ther 2015;5:165. 